\title{
Phosphorus Status in the Soils of Imphal West District, Manipur (India)
}

\author{
Linthoi Watham, Herojit Singh Athokpam*, Nandini Chongtham, K. Nandini Devi, \\ Naorem Brajendra Singh, N. Gopimohan Singh, P.T. Sharma and Punabati Heisnam
}

\author{
College of Agriculture, Central Agricultural University, Imphal - 795004, India
}

*Corresponding author

\begin{tabular}{|l|}
\hline Key w or d s \\
Surface soils, $\mathrm{P}$ \\
fractions, Clay, \\
CEC, EC
\end{tabular}

\section{Introduction}

Phosphorus is the second most critical plant nutrient owing to its important role in root proliferation and thereby atmosphere nitrogen fixation. It is a major component of compound whose functions relate to growth, root development, flowering, and ripening. It also enhance the efficiency of utilization of atmospheric nitrogen and symbiotic process, thereby reducing dependence on nitrogenous

\section{A B S T R A C T}

The phosphorus fractions of the twenty surface soils $(0-15 \mathrm{~cm})$ of Imphal West district, Manipur and their relationship with some physico-chemical properties of the soils were studied. A significant relationship was obtained between organic-P and total-P in the soils. The average Sal-P, Fe-P, Al-P, Red-P, Occl-P and Ca-P content were 8.70, 73.38, 50.83, $82.54,29.00$ and $22.17 \mathrm{ppm}$, respectively. The inorganic $\mathrm{P}$ fractions in the soils were in the order: Red-P > Fe-P > Al-P > Occl-P > Ca-P > Sal-P. Sal-P had a significant correlation with E.C. $\left(\mathrm{r}=0.661^{* *}\right)$ and C.E.C. $\left(\mathrm{r}=0.455^{*}\right)$. Fe-P had a negative correlation with soil $\mathrm{pH}\left(\mathrm{r}=-0.565^{*}\right)$ and positively correlated with O.C. $\left(\mathrm{r}=0.502^{*}\right)$. Al-P had a negatively correlated with soil $\mathrm{pH}\left(\mathrm{r}=0.510^{*}\right)$ and positively correlated with O.C. $\left(\mathrm{r}=0.698^{* *}\right)$, available $\mathrm{N}\left(\mathrm{r}=0.508^{*} *\right)$ and C.E.C. $(\mathrm{r}=0.699 * *)$. Red-P had a significant correlation with C.E.C. $\left(r=0.555^{*}\right)$ and negatively correlated with silt $\left(r=-0.455^{*}\right)$. Occl-P had a significant negative correlation with silt content of the soil $\left(\mathrm{r}=-0.530^{*}\right)$ and positively correlated with C.E.C. $(\mathrm{r}=0.577 * *)$. Ca-P had a positive correlation with E.C. $(\mathrm{r}=$ $\left.0.539^{*}\right)$, clay $\left(\mathrm{r}=0.583^{* *}\right)$ and C.E.C. $(\mathrm{r}=0.605 * *)$ and negative correlation with sand $(\mathrm{r}$ $=-0.500 *)$. Among the different fractions Sal-P, Red-P and Occl-P was positively and significantly correlated with Ca-P $\left(\mathrm{r}=0.534^{*}\right),\left(\mathrm{r}=0.583^{* *}\right)$ and $\left(\mathrm{r}=0.534^{*}\right)$, respectively and negatively correlated with Org-P $\left(\mathrm{r}=-0.563^{*}\right)$ and sal-P. Al-P was positively and significantly correlated with Red-P $(0.506 *)$. 
decreases microbial phosphorus mineralization but $\mathrm{C}$ : $\mathrm{P}$ ratio of $<200$ enhances organic phosphorus mineralization.

In soil, phosphorus $(\mathrm{P})$ exists in both organic as well as inorganic forms. Indian soils usually contain 44 to $3580 \mathrm{mg} \mathrm{kg}^{-1}$ of total P (Kumar, 1999) and traces to $2160 \mathrm{mg} \mathrm{kg}^{-1}$ of organic $P$. The inorganic $\mathrm{P}$ occurs in combinations with various forms of $\mathrm{Al}, \mathrm{Fe}, \mathrm{Mg}, \mathrm{Ca}$ and other elements most of which are not soluble and therefore, not available for both plant and microbial uptake. The insoluble fractions are neither available readily to growing plants nor to micro-organisms and constitute 94 to $99 \%$ of the total P. This fraction is mostly attached to $\mathrm{Fe}$ and $\mathrm{Al}$ in acid soils and to $\mathrm{Ca}$ in slightly acidic to alkaline soils.

Organic P compounds are mostly esters of orthophosphoric acid and have been identified primarily as inositol phosphates, phospholipids and nucleic acids (Havlin et al., 2004)

Phosphorus deficiency in plants has been reported from various parts of India. Information on the chemical forms of $\mathrm{P}$ is fundamental to understand $\mathrm{P}$ dynamics and its interaction in acidic soils which are necessary for management of P (Abolfazli et al., 2012)

Thus the basic idea of this study is to investigate the more actively cyclic forms of organic $\mathrm{P}$ which contribute to the available pool. Among the various inorganic forms, the reductant soluble $\mathrm{P}$ is mostly unavailable to plants and constituting about $19-40 \%$ of the total P in tea soils (Banerjee, 1993), the iron and aluminium phosphate fractions make up $7-17 \%$ of the total $\mathrm{P}$ and is considered to be slowly available pool of $\mathrm{P}$ (Dey and Bhattacharyya 1980). At the same time, organic $\mathrm{P}$ is an important source of plant nutrient in both natural and managed environment, since the mineralization of organic matter and then release of inorganic $\mathrm{P}$ is important for plant uptake. The importance of phosphorus had been reported by many workers but work on different forms of $\mathrm{P}$ and their relationship with soil characteristics in acid soils of Manipur are lacking. Therefore, the present investigation was undertaken to evaluate the different forms of inorganic and organic forms of $\mathrm{P}$ for effective management of Phosphorous.

\section{Materials and Methods}

Twenty surface soil samples $(0-15 \mathrm{~cm})$ for investigation were collected from cultivated farmer`s field of Imphal West district, Manipur. The collected soil samples were passed through $2 \mathrm{~mm}$ sieve for chemical analysis. The $\mathrm{pH}$ was measured in $1: 2.5$, soil: water suspension and total nitrogen (Jackson 1973), C.E.C. (Dewis and Freitas, 1984), soil texture, available $\mathrm{K}, \mathrm{Ca}$ and $\mathrm{Mg}$ (Chopra and Kanwar 1976) and available N (Subbiah and Asija, 1956). The processed soil samples $(<2$ $\mathrm{mm}$ ) were analyzed for soil texture, $\mathrm{pH}, \mathrm{CEC}$, total nitrogen, available nitrogen, $\mathrm{K}, \mathrm{Ca}$ and $\mathrm{Mg}$ using standard procedures as described by Jackson (1973) and Chopra and Kanwar (1976). Organic carbon was determined by wet oxidation method of Walkley and Black (1934). Total phosphorus content of soil sample was determined by perchloric acid (60\%) digestion with concentrated $\mathrm{H}_{2} \mathrm{SO}_{4}$ pretreatment for preliminary oxidation following the method of Mehta et al., (1954) as described by Hesse (1971). The organic phosphorus fractions of the soil sample was determined by pre-extraction of soil with concentrated hydrochloric acid followed by two extractions with $0.5 \mathrm{M}$ sodium hydroxide, one cold and the other at $90^{\circ} \mathrm{C}$ as outline by Mehta et al., (1954). Inorganic phosphorus fractionation of soils was carried out following the modified procedure of Chang and Jackson as outlined by Peterson and Corey (1966). 


\section{Results and Discussion}

\section{Characteristics of the soils}

The physical and chemical properties of the soils are presented in Table 1. Particle size analysis showed that the soils varied from clay to clay loam with a clay value from 34.83 to 83.12 per cent, silt value of 8.18 to 42.50 percent and sand value of 6.20 to 50.90 per cent. The result shows that $\mathrm{pH}$ of the soils ranged from 4.58 to 5.67 (mean 4.98), organic carbon content varied from 11.30 to $35.30 \mathrm{~g}$ $\mathrm{kg}^{-1}$ with mean value $22.20 \mathrm{~g} \mathrm{~kg}^{-1}$. The mean total nitrogen, available nitrogen, available $\mathrm{K}$, $\mathrm{CEC}, \mathrm{EC}, \mathrm{Ca}$ and $\mathrm{Mg}$ of the studied soils was 0.13 per cent, $315.51 \mathrm{~kg} \mathrm{ha}^{-1}, 152.58 \mathrm{~kg} \mathrm{ha}^{-1}$, 16.15 [Cmol $\left.\left(\mathrm{P}^{+}\right) \mathrm{kg}^{-1}\right], 0.22 \mathrm{dSm}^{-1}, 2.81[\mathrm{Cmol}$ $\left.\left(\mathrm{P}^{+}\right) \mathrm{kg}^{-1}\right], 1.86\left[\mathrm{Cmol}\left(\mathrm{P}^{+}\right) \mathrm{kg}^{-1}\right]$, respectively.

\section{Total phosphorus}

The total phosphorus content of the studied soil ranged (Table 2) from 435.00 to 702.40 ppm, with an average of 563.99 ppm. Total phosphorus distribution in the studied soils had consistent trends. Total phosphorus was highly correlated positively with organic $\mathrm{P}$ (r $\left.=0.775^{* *}\right)$ (Table 4$)$. The association between organic $\mathrm{P}$ and total $\mathrm{P}$, which is evident because of higher correlation value of organic $\mathrm{P}$ and total $\mathrm{P}$, had been reported by many workers such as Loganathan and Sutton (1987), Dongale (1993) and Kaistha et al., (1999).

\section{Organic phosphorus}

Organic-P content in the soil ranged from $205.00 \mathrm{ppm}$ to $495.00 \mathrm{ppm}$ with a mean value of 297.38 ppm, accounting $52.73 \%$ of the total P. The high organic-P content in the soils may be due to high organic carbon content. There was no significant correlation with the soil properties. A significant relationship was obtained between organic $\mathrm{P}$ and total $\mathrm{P}$ in the soils $\left(\mathrm{r}=0.775^{* *}\right)$ and negatively correlated with saloid $\mathrm{P}\left(\mathrm{r}=-0.536^{*}\right)$. The result is in close conformity with those reported by Loganath and Sutton (1987), Dongale (1993) and Kaistha et al., (1999).

\section{Inorganic phosphorus}

The total inorganic phosphorus is divided into active and inactive forms. The former consists of Al-P, Fe-P and Ca-P and the latter consists of occluded, reductant-soluble and residual $\mathrm{P}$ (Chang and Jackson 1957). The active forms are the fractions most available to plants, with the degree of availability increasing in the order Ca-P, Fe-P and Al-P in the upland condition (Thomas and Peaslee, 1973).

\section{Saloid phosphorus (Sal-P)}

The saloid $\mathrm{P}$ content in the soils varied from 4.50 to $15.00 \mathrm{ppm}$. The average value of saloid P was $8.70 \mathrm{ppm}$ of the studied soils. Saloid $\mathrm{P}$ was highly and significantly correlated with E.C. $\left(\mathrm{r}=0.661^{* *}\right)$ and C.E.C. $\left(\mathrm{r}=0.455^{*}\right)$. Among the different fractions Sal$\mathrm{P}$ positively and significantly correlated with $\mathrm{Ca}-\mathrm{P}\left(\mathrm{r}=0.534^{*}\right)$ and $\mathrm{Al}-\mathrm{P}\left(\mathrm{r}=0.530^{*}\right)$ and negatively correlated with Org-P $\left(\mathrm{r}=-0.536^{*}\right)$. The low content of saloid $\mathrm{P}$ in the soils might be due to low pH of the soils (Malakar et al., 2015).

\section{Iron phosphorus (Fe-P)}

Iron phosphorus (Fe-P) in the soils ranged from $40.50 \mathrm{ppm}$ to $112.00 \mathrm{ppm}$ with a mean value of $73.38 \mathrm{ppm}$ being greater than the Al$\mathrm{P}$ and constituted $13.01 \%$ of the total P. Fe-P content was negatively and significantly correlated with $\mathrm{pH}\left(\mathrm{r}=-0.565^{*}\right)$ and positively significantly correlated with organic carbon $\left(\mathrm{r}=0.502^{*}\right)$. The positive relationship of organic carbon with Fe-P might be due to the mineralization of organic $\mathrm{P}$ and conversion into iron fraction due to high biological activities in the soils (Sacheti and Saxena, 1973). 
Table.1 Some physico-chemical properties of soils

\begin{tabular}{|l|c|c|}
\hline Soil properties & Range & Mean \\
\hline Clay $(\%)$ & $34.83-83.12$ & 56.95 \\
\hline Silt $(\%)$ & $8.18-42.50$ & 25.37 \\
\hline Sand $(\%)$ & $6.20-50.92$ & 17.69 \\
\hline pH & $4.58-5.67$ & 4.98 \\
\hline EC $\left(\mathrm{dSm}^{-1}\right)$ & $0.14-0.31$ & 0.22 \\
\hline O.C. $\left(\mathrm{g} \mathrm{kg}^{-1}\right)$ & $11.30-35.30$ & 22.20 \\
\hline Total N $(\%)$ & $0.06-0.22$ & 0.13 \\
\hline Available N $\left(\mathrm{kg} \mathrm{ha}^{-1}\right)$ & $225.80-463.42$ & 315.51 \\
\hline Available K $\left(\mathrm{kg} \mathrm{ha}^{-1}\right)$ & $98.00-207.50$ & 152.58 \\
\hline $\mathrm{CEC}\left[\mathrm{Cmol}^{-1}\left(\mathrm{P}^{+}\right) \mathrm{kg}^{-1}\right]$ & $9.20-30.20$ & 16.15 \\
\hline $\left.\mathrm{EC}(\mathrm{dSm})^{-1}\right)$ & $0.14-0.31$ & 0.22 \\
\hline $\mathrm{Ca}\left[\mathrm{Cmol}\left(\mathrm{P}^{+}\right) \mathrm{kg}^{-1}\right]$ & $1.25-4.40$ & 2.81 \\
\hline $\mathrm{Mg}\left[\mathrm{Cmol}^{-1}\left(\mathrm{P}^{+}\right) \mathrm{kg}^{-1}\right]$ & $0.15-4.30$ & 1.86 \\
\hline
\end{tabular}

Table.2 Amount of phosphorous of the soils extracted by various extractants

\begin{tabular}{|c|r|r|r|r|r|r|r|r|}
\hline $\begin{array}{c}\text { Soil } \\
\text { No. }\end{array}$ & \multicolumn{1}{|c|}{ Sal-P } & \multicolumn{1}{|c|}{ Iron-P } & \multicolumn{1}{|c|}{ Al-P } & \multicolumn{1}{|c|}{ Red-P } & Occl-P & Ca-P & Org.-P & Total-P \\
\hline $\mathbf{1}$ & 7.50 & 87.50 & 71.25 & 71.25 & 25.00 & 15.00 & 350.00 & 627.50 \\
\hline $\mathbf{2}$ & 5.00 & 70.50 & 32.60 & 56.00 & 15.00 & 16.25 & 495.00 & 690.35 \\
\hline $\mathbf{3}$ & 6.50 & 112.00 & 41.90 & 57.00 & 37.50 & 10.67 & 425.00 & 690.57 \\
\hline $\mathbf{4}$ & 7.00 & 85.00 & 55.00 & 90.00 & 27.50 & 30.00 & 212.50 & 507.00 \\
\hline $\mathbf{5}$ & 6.75 & 82.50 & 40.00 & 97.00 & 22.50 & 17.00 & 325.00 & 590.75 \\
\hline $\mathbf{6}$ & 9.70 & 76.00 & 45.00 & 81.00 & 34.50 & 22.70 & 262.50 & 531.40 \\
\hline $\mathbf{7}$ & 10.00 & 51.90 & 42.50 & 91.00 & 42.50 & 30.00 & 240.00 & 507.90 \\
\hline $\mathbf{8}$ & 12.33 & 77.50 & 45.50 & 75.50 & 32.50 & 24.50 & 245.00 & 512.83 \\
\hline $\mathbf{9}$ & 7.50 & 62.50 & 33.00 & 67.00 & 10.50 & 23.75 & 317.50 & 521.75 \\
\hline $\mathbf{1 0}$ & 5.50 & 80.00 & 43.60 & 50.00 & 15.00 & 16.25 & 241.00 & 451.35 \\
\hline $\mathbf{1 1}$ & 10.00 & 108.00 & 81.50 & 130.40 & 35.00 & 25.00 & 312.50 & 702.40 \\
\hline $\mathbf{1 2}$ & 7.00 & 58.00 & 37.00 & 87.50 & 23.00 & 15.84 & 288.00 & 516.34 \\
\hline $\mathbf{1 3}$ & 8.60 & 77.50 & 51.80 & 79.00 & 45.00 & 25.50 & 233.50 & 520.90 \\
\hline $\mathbf{1 4}$ & 12.25 & 82.50 & 47.50 & 51.25 & 17.50 & 19.00 & 205.00 & 435.00 \\
\hline $\mathbf{1 5}$ & 4.50 & 40.50 & 25.00 & 69.00 & 32.00 & 21.00 & 350.00 & 542.00 \\
\hline $\mathbf{1 6}$ & 8.25 & 75.00 & 61.00 & 110.00 & 45.00 & 27.50 & 327.50 & 654.25 \\
\hline $\mathbf{1 7}$ & 15.00 & 67.50 & 60.00 & 107.00 & 27.50 & 30.00 & 240.00 & 547.00 \\
\hline $\mathbf{1 8}$ & 9.80 & 45.20 & 62.50 & 69.30 & 17.50 & 14.70 & 257.50 & 476.50 \\
\hline $\mathbf{1 9}$ & 13.50 & 80.00 & 85.00 & 90.00 & 50.00 & 33.20 & 295.00 & 646.70 \\
\hline $\mathbf{2 0}$ & 7.25 & 48.00 & 55.00 & 121.50 & 25.00 & 25.50 & 325.00 & 607.25 \\
\hline Mean & 8.70 & 73.38 & 50.83 & 82.54 & 29.00 & 22.17 & 297.38 & 563.99 \\
\hline
\end{tabular}


Table.3 Simple correlation co-efficient between the different forms of phosphorus and soil properties

\begin{tabular}{|l|l|l|l|l|l|l|l|r|l|}
\hline & & Sal-P & \multicolumn{1}{|c|}{ Fe-P } & \multicolumn{1}{|c|}{ Al-P } & Red-P & \multicolumn{1}{c|}{ Occl-P } & \multicolumn{1}{c|}{ Ca-P } & Org-P & \multicolumn{1}{c|}{ Tot-P } \\
\hline $\mathbf{1}$ & pH & -0.056 & $-0.565^{*}$ & $-0.510^{*}$ & -0.101 & -0.243 & 0.058 & 0.257 & -0.060 \\
\hline $\mathbf{2}$ & E.C & $0.661^{* *}$ & 0.233 & 0.318 & 0.255 & 0.273 & $0.539^{*}$ & -0.200 & 0.112 \\
\hline $\mathbf{3}$ & O.C & 0.428 & $0.502^{*}$ & $0.698^{* *}$ & 0.033 & 0.206 & 0.131 & -0.173 & 0.162 \\
\hline $\mathbf{4}$ & Av. N & 0.326 & 0.167 & $0.508^{*}$ & 0.012 & -0.038 & 0.375 & -0.385 & -0.158 \\
\hline $\mathbf{5}$ & Tot. N & 0.180 & -0.048 & -0.260 & 0.130 & 0.101 & 0.314 & -0.119 & -0.054 \\
\hline $\mathbf{6}$ & Av. K & 0.186 & 0.042 & 0.413 & 0.191 & 0.420 & 0.340 & -0.421 & -0.052 \\
\hline $\mathbf{7}$ & Sand & -0.186 & 0.041 & -0.002 & 0.030 & -0.020 & $-0.500^{*}$ & 0.322 & 0.274 \\
\hline $\mathbf{8}$ & Silt & 0.044 & -0.129 & -0.411 & $-0.455^{*}$ & $-0.530^{*}$ & -0.320 & -0.093 & 0.153 \\
\hline $\mathbf{9}$ & Clay & 0.117 & 0.047 & 0.252 & 0.255 & 0.339 & $0.583 * *$ & -0.193 & 0.375 \\
\hline $\mathbf{1 0}$ & Ca & -0.236 & 0.104 & -0.021 & 0.039 & 0.297 & -0.338 & 0.268 & 0.253 \\
\hline $\mathbf{1 1}$ & Mg & 0.010 & 0.366 & -0.014 & -0.075 & -0.259 & -0.251 & 0.162 & -0.413 \\
\hline $\mathbf{1 2}$ & C.E.C & $0.455^{*}$ & 0.106 & $0.699^{* *}$ & $0.555^{*}$ & $0.577 * *$ & $0.605^{* *}$ & -0.098 & 0.056 \\
\hline
\end{tabular}

Table.4 Simple correlation co-efficient among the different forms of phosphorus

\begin{tabular}{|c|l|c|r|r|c|c|c|c|}
\hline Sl.No. & Forms & Sal-P & Fe-P & Al-P & Red-P & Occl-P & Ca-P & Org-P \\
\hline $\mathbf{1}$ & Sal-P & & & & & & & \\
\hline $\mathbf{2}$ & Fe-P & 0.092 & & & & & & \\
\hline $\mathbf{3}$ & Al-P & $0.530^{*}$ & 0.368 & & & & & \\
\hline $\mathbf{4}$ & Red-P & 0.275 & -0.006 & $0.506^{*}$ & & & & \\
\hline $\mathbf{5}$ & Occl-P & 0.321 & 0.210 & 0.409 & 0.441 & & & \\
\hline $\mathbf{6}$ & Ca-P & $0.534^{*}$ & 0.141 & 0.385 & $0.583^{* *}$ & $0.536^{*}$ & & \\
\hline $\mathbf{7}$ & Org-P & $-0.536^{*}$ & 0.129 & -0.206 & 0.122 & -0.095 & -0.444 & \\
\hline $\mathbf{8}$ & Tol-P & -0.151 & 0.436 & 0.343 & 0.379 & 0.349 & -0.018 & $0.775^{* *}$ \\
\hline
\end{tabular}

\section{Aluminum phosphorus (Al-P)}

Al-P content in the soils was ranged from $25.00 \mathrm{ppm}$ to $85.00 \mathrm{ppm}$. The mean value of Al-P was 50.83 ppm being greater than the Ca-P and constituted $9.01 \%$ of the total $\mathrm{P}$ The low Al-P content in the soils to be indicative of strong weathering under well drained humid tropics (Sarkar et al., 2014). Al-P content was negatively and significantly correlated with $\mathrm{pH}\left(\mathrm{r}=-0.510^{*}\right)$ and positively significantly correlated with organic carbon $(\mathrm{r}=0.698 * *)$, available nitrogen $\left(\mathrm{r}=0.508^{*}\right)$ and C.E.C $\left(\mathrm{r}=0.699^{* *}\right)$. Among the different fractions Al-P positively and significantly correlated with Red-P
$(0.506 *)$ and Sal-P $(\mathrm{r}=0.530 *)$ (Table 3$)$.

\section{Reductant soluble phosphorus (Red-P)}

Red-P in the studied soils ranged from 50.00 $\mathrm{ppm}$ to $130.40 \mathrm{ppm}$ with a mean value of $82.54 \mathrm{ppm}$ constituted $14.6 \%$ of the total $\mathrm{P}$ and it was the highest inorganic $P$ fraction of the soil. Red-P was negatively and significantly correlated with silt fraction $(\mathrm{r}=$ $\left.0.455^{*}\right)$ and positively significantly correlated with CEC $\left(\mathrm{r}=0.555^{*}\right)$.

Red-P was positively and significantly correlated with Ca-P ( $\left.\mathrm{r}=0.583^{* *}\right)$ and Al-P ( $\mathrm{r}$ $\left.=0.506^{*}\right)$. Such correlation suggests that 
these $p$ fractions are dynamic equilibrium in the soil and transformation among these fractions would be the key to understand the potential P release and availability to the plants.

\section{Occluded phosphorus (Occl-P)}

Occl-P content in the soil varied from 10.50 ppm to $50.00 \mathrm{ppm}$ with a mean value of occl-P was $29.00 \mathrm{ppm}$. Occl-P was negatively and significantly correlated with silt fraction $(\mathrm{r}=$ $0.530 *$ ) and positively and significantly correlated with C.E.C. $\left(\mathrm{r}=0.577^{* *}\right)$. Again Occl-P was found to be positively and significantly correlated with $\mathrm{Ca}-\mathrm{P}\left(\mathrm{r}=0.536^{*}\right)$.

\section{Calcium phosphorus (Ca-P)}

Amount of Ca-P ranged from $10.67 \mathrm{ppm}$ to $33.20 \mathrm{ppm}$ with a mean value of $22.17 \mathrm{ppm}$. The calcium $\mathrm{P}$ content in the soil was lower than the Fe-P and Al-P and constituted 3.93\% of the total P. This might be due to the low reported by Sarkar et al., (2015).Ca-P was significantly correlated with E.C. $(\mathrm{r}=0.539 *)$, clay fraction $\left(\mathrm{r}=0.583^{* *}\right)$ and correlated C.E.C. $\quad\left(\mathrm{r}=0.605^{* *}\right)$ negatively and significantly correlated with sand fraction $(r=$ $0.500 *)$.

In conclusion, the relative abundance of inorganic forms also gives an indication of the degree of chemical weathering of the soils-the strongly weathered ones have a higher proportion of inactive inorganic forms and Fe-P than the others (Chang and Jackson, 1975). The average Sal-P, Fe-P, Al-P, Red-P, Occl-P and Ca-P content were 8.70, 73.38, 50.83, 82.54, 29.00 and $22.17 \mathrm{ppm}$, respectively. For the soil studied the amount of inorganic $\mathrm{P}$ fractions was in the order: Red-P > Fe-P > Al-P > Occl-P > $\mathrm{Ca}-\mathrm{P}>\mathrm{Sal}-\mathrm{P}$. A similar trend had been reported by several authors (Uzu et al., 1975; Ibia and Udo, 1993; Loganathan et al., 1982; Loganathan and Sutton, 1987 and Osodeke and Kamalu, 1962). The low percentages of Sal-P and $\mathrm{Ca}-\mathrm{P}$ in the soils are due to the high rainfall leading to the leaching losses of bases resulting to low $\mathrm{pH}$ of these soils. Similar result was also reported by Loganathan and Sutton (1987). The Fe-P dominated the active $\mathrm{P}$ forms in the soils which may be due to intense chemical weathering of soils in these areas.

\section{References}

Banerjee, B. 1993. Tea production and processing. Oxford and IBH Pub. Co., New Delhi, pp. 188-225.

Chang, S.C. and Jackson, M.L. 1957. Fractionation of soil phosphorus. Soil Science. 84: 133-144.

Chopra, S.L. and Kanwar, J.S. 1976. Analytical Agricultural Chemistry. Kalyani Publisher Ludhiana, New Delhi.

Dewis, J. and Freitas, F. 1984. Physical and chemical methods of soil and water analysis. Oxford and IBH Pub. Co., New Delhi. pp. 51-106.

Dey, S.K. and Bhattacharyya, N.G. 1980. Studies on soil phosphate. Two Bud. 27: 21-23

Dongale, J. H. 1993. Depthwise distribution of different forms of phosphorus in lateritic soils of coastal region. Journal of the Indian Society of Soil Science. 41: 62-66.

Havlin, J.L., Beaton, J.D., Tisdale, S.L. and Nelson, W.L. 2004. Soil Fertility and fertilizers: An introduction to nutrient management, Sixth Edn. Pearson Edn. Pvt. Ltd., New Delhi. pp 162.

Hesse, P.R. 1971. A textbook of soil chemical analysis. John Murray (Publishers) Ltd. 50 Albemarle Street, London, W1X4BD.

Ibia, T.O. and Udo, E.J. 1993. Phosphorus forms and fixation of representative soils in Akwa Ibo, State of Nigeria. Geoderma. 95-106.

Jackson, M.L. 1973. Soil Chemical Analysis. Prentice Hall of India Private Limited, New Delhi.

Kaistha, B.P., Sharma, P.C. and Dubey, Y.P. 1999. Effect of manure and phosphorus on the inorganic phosphorus fractions in mountain soil of Himalayas. Crop Research. 18(2): 206-210.

Khaswa, S.L., Dubey, R.K., Tiwari, R.C., Singh, S., Choudhary, B. S. and Singh, I. 
2014 Nitrogen and phosphorous content and uptake, soil nutrient balance and soybean productivity under different levels and sources of phosphorous and plant growth regulators in sub-humid Rajasthan.. 9 (1): 1107-1112

Kokani, J.M., Shah, k.a., Tandel, B.M. and Bhimani, G.J. 2015. Effect of FYM, phosphorous and sulphur on yield of summer Black gram and post harvest nutrient status of soils. The Bioscan. 10(1): 379-383.

Loganathan, P., Dayaratne, M.N. and Shanmuganatham. 1982. Evaluation of the phosphorus states of some coconut growing soils of Sri Lanka. Jornal of agricultural Sciences. 99: 25-33.

Loganathan, P. and Sutton, P.M. 1987. Phosphorus fractions and availability in soils formed on different geological deposits in the Niger delta area of Nigeria. Soil Science. 143(1): 16-25.

Malakar, H, Gosh, D., Chatterjee, S. and Debnath, A. 2015. Inorgnaic and organic soil phosphorous fractions in humid tropical tea plantations of West Bengal, India. The Bioscan. 10(1): 313-318.

Mehta, N.C., Legg, J.O, Goring C.A.I. and Black, C.A., 1954. Soil Science Society of American Proceeding. 18: 443.

Osodeke, V.E. and Kamalu, O.J. 1962. Phosphorus status of Hevea growing soils of Nigeria. Indian Journal of Natural Rubber Research. 5: 107-112

Peterson, G.W. and Corey, R.B. 1966. A modified Chang and Jackson procedure for routine fractionation of inorganic soil phosphates. Soil Science. 163: 31-36

Sacheti, A. K. and Saxena, S. N. 1973. Relationship between some soil characteristics and various inorganic phosphate fractions of soils of Rajasthan. Journal of the Indian Society of Soil Science. 21: 143-149.

Sarkar,D., Haldar, A. and Mandal, D. 2014. Forms of phosphorous in relation to soil maturity along a toposequence under hot, dry sub-humid agro-ecological sub-region of West Bengal. Journal of the Indian Society of Soil Science. 62 (1): 29-37.

Subbiah, B.V. and Asija, G.L. 1956. A rapid procedure for estimation of available $\mathrm{N}$ in soils. Current Science. 25: 259-260.

Sureshkumar, P. 1999. Final report of ICAR Adhoc Scheme on variability in Iron and Zinc availability in the Laterite and Lateritic Soils of Central Kerala with Reference to Rice Nutrition. Radiotracer Laboratory, College of Horticultural University, Thrissur

Thomas, G.W. and Peaslee, D.E. 1973. Testing soil for phosphorus in soil testing and plant analysis. Walsh and JD Beaton (eds.). Soil Science Society of America, Madison Wis. pp 115-132

Uzu, F.O., Juo, A.S.R. and Fayemi, A.P. 1975. Forms of phosphorus in some important agricultural soils of Nigeria. Soil Science. 120: $212-218$

Wakley, A. and Black, I.A. 1934. An estimation of the Degtjareff method for determining soil organic matter and a proposed modification of the chromic acid titration method. Soil Science. 37: 29-38.

\section{How to cite this article:}

Linthoi Watham, Herojit Singh Athokpam, Nandini Chongtham, K. Nandini Devi, Naorem Brajendra Singh, N. Gopimohan Singh, P.T. Sharma and Punabati Heisnam. 2018. Phosphorus Status in the Soils of Imphal West District, Manipur (India). Int.J.Curr.Microbiol.App.Sci. 7(07): 3871-3877. doi: https://doi.org/10.20546/ijcmas.2018.707.450 